\title{
Levels of insulin-like growth factor in bovine, goat, and sheep milk in different lactation periods: The etiological factor of cancer in humans
}

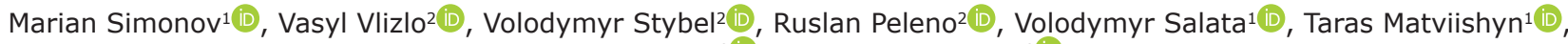 \\ Mariia Khimych ${ }^{3}$ (D) and Oleksii Gorobei ${ }^{3}$ (D)
}

1. Faculty of Social Development and Health, Stepan Gzhytskyi National University of Veterinary Medicine and Biotechnologies Lviv, Lviv, Ukraine; 2. Faculty of Veterinary Medicine, Stepan Gzhytskyi National University of Veterinary Medicine and Biotechnologies Lviv, Lviv, Ukraine; 3. Faculty of Veterinary Medicine, Odesa State Agrarian University, Odesa, Ukraine.

Corresponding author: Marian Simonov, e-mail: m.simonov@ukr.net

Co-authors: VV: buiatricsua@gmail.com, VS: vstybel@ukr.net, RP: andriyovich30@ukr.net, VSa: salatavolod@ukr.net, TM: matviishin-taras@ukr.net, MK: khimichms@gmail.com,OG: gorobeyam@gmail.com

Received: 26-05-2021, Accepted: 26-10-2021, Published online: 10-12-2021

doi: www.doi.org/10.14202/IJOH.2021.246-250 How to cite this article: Simonov M, Vlizlo V, Stybel V, Peleno R, Salata V, Matviishyn T, Khimych M, Gorobei O (2021) Levels of insulin-like growth factor in bovine, goat, and sheep milk in different lactation periods: The etiological factor of cancer in humans, Int. J. One, Health, 7(2): 246-250.

\begin{abstract}
Background and Aim: Despite the positive aspects of consuming dairy products, there are also some reservations. Recently, a large number of publications have demonstrated convincing evidence of a relationship between the intake of dairy products and the development of cancer in humans. This study aimed to determine the level of insulin-like growth factor [IGF], which can cause cancer in consumers, in the milk of farm animals (cows, goats, and sheep) obtained at different stages of lactation.

Materials and Methods: Enzyme-linked immunosorbent assay and statistical method were used for data processing. The IGF level in milk was determined using an enzyme-linked immunosorbent assay. Milk was collected from cows of Holstein and Ukrainian Black-and-White dairy breed, goats of Alpine and Saanen breed, and sheep of Tsigai and East Friesian breed. Milk samples in cows were collected at the beginning, on the peak, and at the end of lactation.

Results: The obtained results showed that the highest IGF level was detected in milk obtained at the beginning of lactation, but its level depended on the animal species. More specifically, the highest level of the hormone was typical for goat's milk and for cow's milk of Holstein breed. Slightly lower values were revealed in the milk of cows of Black-and-White Ukrainian breed and sheep. During lactation, the absolute content of IGF in the milk of all studied animal species decreased. It should be noted that the most pronounced decrease in the IGF level in milk during lactation was noted in sheep (25-40 times), and minor changes were observed in goats (12-14 times). The results also showed that there were individual variations in the IGF level in milk in farm animals.
\end{abstract}

Conclusion: The highest IGF level was noted in goat's milk, and the lowest level was observed in sheep's milk. Cow's milk, in this regard, had an intermediate IGF level. The level of this particular hormone depends on the period of lactation and the individual characteristics of the animal. It is advisable to include IGF as one of the assessment factors of dairy products' safety because this hormone can cause cancer in consumers of milk and dairy products.

Keywords: cows, goats, insulin-like growth factor, lactation, milk, sheep.

\section{Introduction}

Milk and dairy products are an essential part of our diet. They supply native proteins, polyunsaturated fatty acids, phosphatides, minerals, vitamins, and other biologically active substances in optimal proportions. Consumption of dairy products helps to strengthen the body's defense mechanisms as they are a source of beneficial microflora [1-3]. Despite the positive aspects of consuming dairy products, there are also some reservations. Recently, a large number of publications have demonstrated convincing evidence of a relationship between the intake of dairy products and

Copyright: Simonov, et al. This article is an open access article distributed under the terms of the Creative Commons Attribution 4.0 International License (http://creativecommons.org/licenses/ by/4.0/), which permits unrestricted use, distribution, and reproduction in any medium, provided you give appropriate credit to the original author(s) and the source, provide a link to the Creative Commons license, and indicate if changes were made. The Creative Commons Public Domain Dedication waiver (http:// creativecommons.org/ publicdomain/zero/1.0/) applies to the data made available in this article, unless otherwise stated. the development of cancer in humans. For instance, potential mechanisms underlying the relationships between milk consumption and the development of proliferative processes in the prostate gland have been established [4,5]. Other researchers [6] have found an association between milk consumption and the development of colorectal cancer. Ovarian [7], breast [8,9], liver [10], and other cancers have also been reported.

Insulin-like growth factor (IGF)-1 in milk and dairy products may be one of the etiopathogenetic factors in the development of cancer [11-14]. It has been established [15] that high IGF-1 levels in milk serum contribute to the growth of human colon cancer cell culture. IGF is a protein similar in structure and function to insulin. It participates in the endocrine, autocrine, and paracrine regulations of the processes of growth, development, and differentiation of cells and tissues in the body. IGF-1 is also a crucial endocrine mediator of somatotropic hormone action; hence, it is also called somatomedin [16-18]. IGF consists of 
a single polypeptide chain of 70 amino acid residues with three intramolecular disulfide bridges. It should be mentioned specifically that the aforementioned hormone is not a species-specific one and once consumed, it is recognized by the recipient's body as its own; therefore, its level and corresponding metabolic effect increase. For example, an increase in the IGF-1 levels in the blood of people who consume large amounts of dairy products in their diet has been shown [19].

The vast majority of researches dedicated to the IGF refer to humane medicine, and there are almost no data available on its transition into livestock products. Therefore, this study aimed to determine the IGF level in cattle (bovine, goat, and sheep) milk collected during different lactation periods. The results can form the basis for studying the etiology and pathogenesis of malignancies as well as for the concept of a "safe dairy product." In particular, we recommend that milk high in IGF levels should be processed into dairy products and that milk low in IGF levels should be consumed as it is.

\section{Materials and Methods}

\section{Ethical approval}

The local ethics committee was not consulted for approval of these studies, as all manipulations were performed only with milk.

\section{Study period, area, and sample collection}

The IGF level was determined in bovine, goat, and sheep milk collected at different stages of the lactation period (10 samples of each kind). Milk was collected during morning milking in sterile containers. Three spot milk samples were obtained from each animal, that is, $40 \pm 3 \mathrm{~mL}$ at the beginning phase, in the middle phase, and at the end phase of milking. The spot samples were then mixed to receive a composite sample. Subsequently, milk was transported to the laboratory using a hermetically sealed refrigerator container, allowing a temperature of $6 \pm 2{ }^{\circ} \mathrm{C}$. The samples were transported to the laboratory within $2 \mathrm{~h}$ of the collection.

Milk samples were collected from Holstein cows (second to third lactation, yielding 8200-9300 kg of milk in the previous lactation period), Ukrainian Black-and-White cows (second to fifth lactation, yielding 5100-5700 kg of milk), Tsigai sheep (second lactation, yielding 130-150 kg of milk), East Friesian sheep (third lactation, yielding $500-550 \mathrm{~kg}$ of milk), Alpine goats (third lactation, yielding $830-870 \mathrm{~kg}$ of milk), and Saanen goats (third to fourth lactation, yielding $750-800 \mathrm{~kg}$ of milk). Bovine milk samples were collected at the beginning, peak, and end of lactation, namely, on 10-16, 80-90, and 265-280 days of the lactation period. Goat milk samples were collected on days 3-5, 124-131, and 239-246 of the lactation period, and sheep milk samples were collected on days 2-5, 23-28, and 102-106 of the lactation period.

The cows and sheep were kept at a farm in the village of Selysko, Pustomyty district, Lviv region,
Ukraine. Milk samples from goats were drawn at a dairy farm in the village of Uhersko, Stryi district, Lviv region, Ukraine.

\section{Research methods and sample preparation}

The IGF level was determined at the laboratory of the Department of Veterinary and Sanitary Inspection of S. Z. Gzhytskyi National University of Veterinary Medicine and Biotechnologies in Lviv by enzyme-linked immunosorbent assay using DRG test kits (Germany) and a Stat-Fax analyzer (ChroMate-4300, USA). When setting up the methodology, requirements specified by the test system manufacturer were followed, and all samples were examined in duplicates. A total of 80 samples, 10 from each breed of each animal species, were analyzed.

The selected milk samples were skimmed by centrifugation at $9000 \mathrm{rpm}$ for $20 \mathrm{~min}$ at $4^{\circ} \mathrm{C}$. The skimmed samples were diluted twice with distilled water, and casein was removed from them by bringing the $\mathrm{pH}$ up to 4.6 using $2 \mathrm{~N} \mathrm{HCl}$. Serum for subsequent studies was centrifuged at $1500 \mathrm{rpm}$ for $15 \mathrm{~min}$.

\section{Statistical analysis}

The data were processed in Excel 2010, calculating the arithmetic mean (M), statistical error of arithmetic mean (m), and probability of difference between the arithmetic mean of two ordered series. $p<0.05$ was considered as statistically significant.

\section{Results}

The tests used to determine the IGF levels in bovine milk showed the highest level at the beginning of lactation (Figure-1). Up to days $80-90$ of the lactation period, the hormone level decreased $(p<0.001)$ by 17.5 times in the milk of Holstein cows and by 13.9 times in the milk of Ukrainian Black-and-White breed. Compared with the levels at the beginning of lactation, at its final stage, the levels were 26.3 and 25.8 times lower, respectively $(\mathrm{p}<0.001)$. The comparison of the hormone level in bovine milk from two breeds showed slightly higher values in yields of Holstein cows, but a reliably significant difference was established only at the beginning of lactation. In this way, the difference was $44.5 \%(p<0.05)$.

Attention should be paid to the wide index limits within one group of animals. On days 10-16, the IGF-1 level in the milk of Holstein cows ranged from

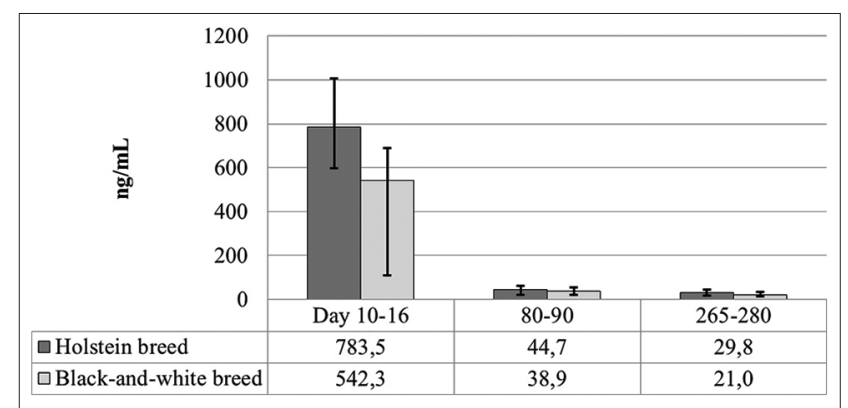

Figure-1: Insulin-like growth factor concentration in bovine milk; $\mathrm{n}=10$. 
598.7 to $1007.5 \mathrm{ng} / \mathrm{mL}$, on days $80-90$, it ranged from 21.4 to $60.2 \mathrm{ng} / \mathrm{mL}$, and on days $265-280$, it ranged from 17.4 to $45.5 \mathrm{ng} / \mathrm{mL}$. In parallel, the index variations in the milk of Ukrainian Black-and-White dairy cows were between 109.7 and $690.6 \mathrm{ng} / \mathrm{mL}$ on days $10-16$, between 21.0 and $55.1 \mathrm{ng} / \mathrm{mL}$ on days $80-90$, and between 12.4 and $35.4 \mathrm{ng} / \mathrm{mL}$ on days $265-280$ of the lactation period.

As shown in Figure-2, the IGF-1 levels in goat milk were also high at the beginning of lactation, irrespective of breed, and decreased during the period of high milk yields and onward until the end of lactation. Namely, in the milk of Alpine goats, the IGF-1 level decreased 9.9-fold $(p<0.001)$ before the peak lactation period and by another $41 \%(p<0.01)$ at the end of lactation. Similarly, in the milk of Saanen goats, the IGF-1 level in milk decreased 11.2-fold $(\mathrm{p}<0.001)$ before the peak lactation period and by another $11.8 \%$ $(p<0.1)$ at the end of lactation. No significant difference was found between the milk values of the two goat breeds.

The tests of milk samples from 10 goats of Saanen breed, which were on days 3-5 of the lactation period, showed practically the same level of IGF-1 $(710.1-750.6 \mathrm{ng} / \mathrm{mL})$. Further, the level of the tested hormone varied widely from 50.5 to $74.2 \mathrm{ng} / \mathrm{mL}$ on days $124-131$ and from 42.1 to $70.4 \mathrm{ng} / \mathrm{mL}$ on days 239-246. In the milk received from Alpine goats, the individual variations of the IGF-1 levels ranged from 605.9 to $775.4 \mathrm{ng} / \mathrm{mL}$ at the beginning of lactation, from 58.9 to $81.4 \mathrm{ng} / \mathrm{mL}$ at its peak, and from 35.5 to $67.8 \mathrm{ng} / \mathrm{mL}$ at the end of the lactation period.

The results of sheep milk testing demonstrated (Figure-3) the same dynamics of change as in bovine and goat milk. The highest IGF-1 level was established on days $2-5$ of the lactation period, which significantly $(p<0.01)$ decreased 12 -fold until days 102-106, regardless of breed. Before the end of the lactation period, the IGF-1 level in the milk of Tsigai and East Friesian sheep decreased by another 2.1 and 3.4 times $(p<0.01)$, respectively. In contrast to the milk yielded from goats, the limits of the IGF-1 levels differed 10 -fold (from 65.6 to $660.0 \mathrm{ng} / \mathrm{mL}$ ) in different sheep milk samples at the beginning of the lactation period.

It can be noted from the data reported in Figures-1-3, a high IGF level was recorded in the milk

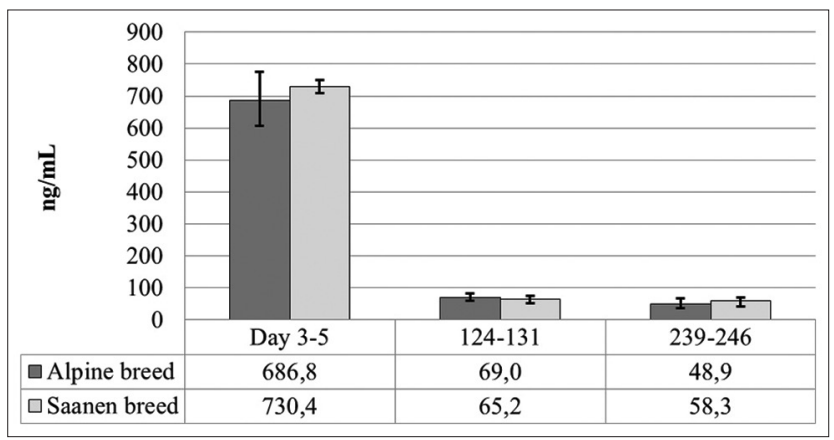

Figure-2: Insulin-like growth factor concentration in goat milk; $\mathrm{n}=10$. of Holstein cows at the beginning of lactation. During the same period, the lowest level was recorded in the milk of Tsigai sheep. At the peak of the lactation period, high levels of the hormone were recorded in goat milk. In comparison with the milk received from cows, the difference was $45.9-77.4 \%(p<0.01)$ and that from sheep was 2-2.6 times higher $(p<0.001)$. At the end of lactation, the values were $64.1-177.6 \%(\mathrm{p}<0.05-0.001)$ and 3.8-6.1 $(\mathrm{p}<0.001)$ times higher, respectively.

The most statistically significant decrease in the IGF-1 level during the lactation period was observed in sheep milk, and the lowest decrease was noted in goat milk.

\section{Discussion}

Increased risk of cancer in humans as a result of the consumption of milk and dairy products with a high content of IGF [11-19] is a known etiological factor in the development of neoplastic processes. Accordingly, the lower the content level of this hormone in milk, the lower the risk. However, the level of this hormone in milk depends primarily on the physiology of the animal rather than on anthropogenic influences. At the same time, people can choose the methods of technological processing of milk before it becomes available for consumption, thus adjusting the content of this hormone in the final product.

A high IGF level in cattle milk at the beginning of lactation, in our opinion, may be due to the need to stimulate metabolic processes, growth, and development of the litter, since during early periods of postnatal ontogenesis, their endocrine system remains immature. In addition, the IGF-1 level in milk depends on its level in the blood. Specifically, a positive correlation has been found between the IGF-1 levels in bovine blood and milk [20]. In turn, the IGF-1 level in the blood depends on the levels of other hormones, which are correlated with the former one [21]. Along with other hormones, IGF-1 is involved in the formation of lactation dominance and contributes to overcoming the energy deficit, which is inherent to ruminants at the beginning of lactation $[22,23]$.

Our studies have shown high levels of the studied hormone in the cattle milk at the early stages of lactation, as also evidenced by other researchers who have established high IGF-1 levels in the colostrum [24].

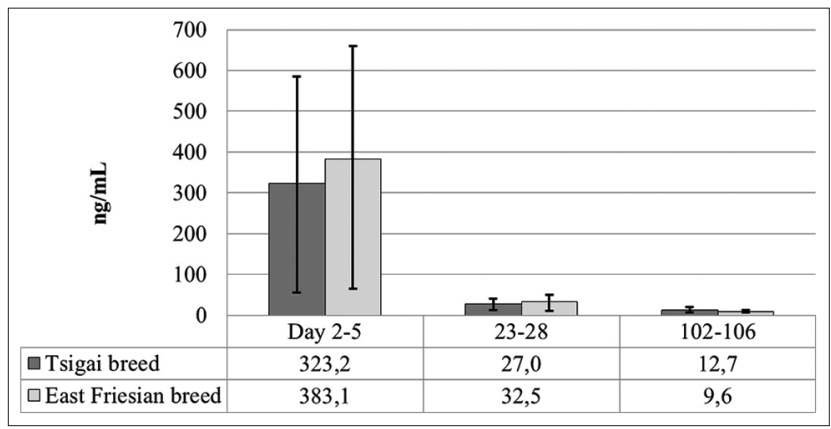

Figure-3: Insulin-like growth factor concentration in sheep milk; $\mathrm{n}=10$. 
Reduced IGF-1 levels in milk received from animals during peak milk yield can be explained by its decrease in blood levels and a parallel increase in milk yields. Several researchers [25] also indicate the existence of a negative correlation between the amount of milk received and hormone levels in milk.

Considering that the minimum and maximum IGF-1 levels in milk of the same animal species differ by several times, it can be assumed that it depends on their diet formulation, body weight, genetic traits, and clinical condition. This has also been pointed out by other researchers [25]. Likewise, data available in the literature [26] show that the IGF-1 levels are dependent on the metabolic status of animals during the dry period. Therefore, further studies involving wider representative sampling of animals would be advisable to obtain more reliable data.

Our study has established no breed-specific features of the IGF-1 level in milk, except for reliably a higher level of the hormone in milk of Holstein cows than in Ukrainian Black-and-White dairy cows at the beginning of lactation, which may be due to the higher productivity of the first breed.

It should be noted that a necessity arose to develop the concept of "safe milk," in which, as one of the factors of its evaluation, it would be advisable to include the determination of the IGF level. Milk collected from the cattle at the early stages of lactation contains high IGF-1 levels and, therefore, may promote active cell growth, which is undesirable for patients with neoplasms. In contrast, at the later stages of lactation, milk is more suitable for consumption in its natural form. This has recently been discussed by scientists from different countries [19,27]. They point to the increased effect of milk and dairy products on proliferative processes in humans.

Considering this, there has been a long-standing worldwide debate on the use of somatotropin in animals to increase milking. In recent decades, the administration of a somatotropic hormone to dairy cows has been prohibited. Such prohibition has been in place since 1990 in the European Union, and later, it was introduced in Canada, Australia, New Zealand, Japan, Israel, and Argentina [28]. Indeed, the artificial increase in the somatotropin hormone level in the blood of cows induces the accumulation of IGF-1 synthesis and its release into milk, which, in turn, would constitute a potential threat to human health for its use in its native condition.

\section{Conclusion}

The highest IGF levels in milk were recorded during the initial stages of lactation in cows (542.3-783.5 ng/mL), goats (686.8-730.4 ng/mL), and sheep (323.2-381.1 ng/mL). During the lactation period, a decrease in the hormone level was recorded. The highest absolute level of the tested hormone was recorded in the milk of goats and the lowest level was recorded in the milk of sheep. Bovine milk had an intermediate IGF level. An exception was the milk of Holstein cows received at the beginning of lactation. Significant individual characteristics of animals regarding the excretion of IGF with milk have been revealed. They were most pronounced in the studies of sheep (tenfold) and least pronounced in the studies of goats (by 40 units). The findings can be used for the development of a "safe milk" concept with its subsequent application in breeding and production of ecological products. Based on the results of research, it is recommended to use milk obtained from farm animals in the early stages of lactation for the production of dairy products. Technological stages of milk processing, including the influence of high temperatures, skimming, homogenization of milk, and its fermentation, can reduce the IGF level (or destroy this hormone completely), which, by its nature, is a protein. Accordingly, the lower the IGF-1 level in a dairy product, the smaller its potential threat as an etiological factor in the development of proliferative processes in the consumer. Instead, milk obtained from animals in the later stages of the lactation period (second and third) should be subjected to "gentle" technological treatments to preserve its useful properties.

\section{Authors' Contributions}

MS, VV, and VS: Supervision, conception, and design of the study. VSa and TM: Sample collection and preparation. MK and OG: Conducted research and statistical processing of results. MS, RP, VV, and VS: Interpretation of the data and drafted and revised the manuscript. All authors read and approved the final manuscript.

\section{Acknowledgments}

The authors are thankful to Stepan Gzhytskyi National University of Veterinary Medicine and Biotechnologies, Lviv, Ukraine, for providing the necessary facilities for this study. The authors did not receive any funds for this study.

\section{Competing Interests}

The authors declare that they have no competing interests.

\section{Publisher's Note}

Veterinary World (Publisher of International Journal of One Health) remains neutral with regard to jurisdictional claims in published institutional affiliation.

\section{References}

1. Slyvka, I., Tsisaryk, O., Musiy, L. and Skulska, I. (2017) The use of bacconcentrate Herobacterin in brine cheese technology. Ukr. J. Food Sci., 11(4): 81-89.

2. Musiy, L., Tsisaryk, O., Slyvka, I., Mykhaylytska, O. and Gutyj, B. (2017) Research probiotic properties of cultured butter during storage. East. Eur. J. Enterprise Technol., 3(11): 31-36

3. Slyvka, I., Tsisaryk, O., Dronyk, G. and Musiy, L. (2018) Strains of lactic acid bacteria isolated from traditional Carpathian cheeses. Regul. Mech. Biosyst., 9(1): 62-68. 
4. Park, S.W., Kim, J.Y., Kim, Y.S., Lee, S.J., Lee, S.D. and Chung, M.K. (2014) A milk protein, casein, as a proliferation promoting factor in prostate cancer cells. World $J$. Mens Health, 32(2): 76-82.

5. Harrison, S., Lennon, R., Holly, J., Higgins, J.P.T., Gardner, M., Perks, C., Gaunt, T., Tan, V., Borwick, C., Emmet, P., Jeffreys, M., Northstone, K., Rinaldi, S., Thomas, S., Turner, S.D., Pease, A., Vilenchick, V., Martin, R.M. and Lewis, S.J. (2017) Does milk intake promote prostate cancer initiation or progression via effects on insulin-like growth factors (IGFs)? A systematic review and meta-analysis. Cancer Causes Control, 28(6): 497-528.

6. Um, C.Y., Fedirko, V., Flanders, W.D., Höflich, C., Wirthgen, E. and Bostick, R.M. (2017) Circulating insulin-like growth factor-related biomarkers: Correlates and responses to calcium supplementation in colorectal adenoma patients. Mol. Carcinog., 56(9): 2127-2134.

7. Yahya, M.A., Sharon, S.M., Hantisteanu, S., Hallak, M. and Bruchim, I. (2018) The role of the insulin-like growth factor 1 pathway in immune tumor microenvironment and its clinical ramifications in gynecologic malignancies. Front Endocrinol., 9: 297.

8. Tamimi, R.M., Colditz, G.A., Wang, Y., Collins, L.C., Hu, R., Rosner, B., Irie, H.Y., Connolly, J.L. and Schnitt, S.J. (2011) Expression of IGR 1 in normal breast tissue and subsequent risk of breast cancer. Breast Cancer Res Treat., 128(1): 243-250.

9. Braak, B., Siezen, C., Speksnijder, E.N., Koedoot, E., van Steeg, H., Salvatori, D.C., van de Water, B. and van der Laan, J.W. (2015) Mammary gland tumor promotion by chronic administration of IGF1 and the insulin analogue AspB10 in the p53R270H/ $/{ }^{+}$WAPCre mouse model. Breast Cancer Res., 17(1): 14.

10. Duarte-Salles, T., Fedirko, V., Stepien, M., Trichopoulou, A., Bamia, C., Lagiou, P., Lukanova, A., Trepo, E., Overvad, K., Tjønneland, A., Halkjaer, J., Boutron-Ruault, M.C., Racine, A., Cadeau, C., Kühn, T., Aleksandrova, K., Trichopoulos, D., Tsiotas, K., Boffetta, P., Palli, D., Pala, V., Tumino, R., Sacerdote, C., Panico, S., Bueno-deMesquita, H.B., Dik, V.K., Peeters, P.H., Weiderpass, E., Torhild Gram, I., Hjartåker, A., Ramón Quirós, J., Fonseca-Nunes, A., Molina-Montes, E., Dorronsoro, M., Navarro Sanchez, C., Barricarte, A., Lindkvist, B., Sonestedt, E., Johansson, I., Wennberg, M., Khaw, K.T., Wareham, N., Travis, R.C., Romieu, I., Riboli, E. and Jenab, M. (2014) Dairy products and risk of hepatocellular carcinoma: The European prospective investigation into cancer and nutrition. Int. J. Cancer, 135(7): 1662-1672.

11. Qin, L., He, K. and Xu, J. (2009) Milk consumption and circulating insulin-like growth factor-I level: A systematic literature review. Int. J. Food Sci. Nutr., 60(7): 330-340.

12. Ma, J., Giovannucci, E., Pollak, M., Chan, J.M., Gaziano, J.M., Willett, W. and Stampfer, M.J. (2011) Milk intake, circulating levels of insulin-like growth factor-I, and risk of colorectal cancer in men. J. Natl. Cancer Inst., 93(17): 1330-1336.

13. Nielsen, T.S., Purup, S., Wärri, A., Godschalk, R.W. and Hilakivi-Clarke, L. (2011) Effects of maternal exposure to cow's milk high or low in isoflavones on carcinogen-induced mammary tumorigenesis among rat offspring.
Cancer Prev. Res. (Phila)., 4(5): 694-701.

14. Yu, H. and Rohan, T. (2020) Role of the insulin-like growth factor family in cancer development and progression. $J$. Natl. Cancer Inst., 92(18): 1472-1489.

15. Purup, S., Vestergaard, M., Pedersen, L. and Sejrsen, K. (2007) Biological activity of bovine milk on proliferation of human intestinal cells. J. Dairy Res., 74(1): 58-65.

16. Partridge, L., Alic, N., Bjedov, I. and Piper, M.D. (2011) Ageing in drosophila: The role of the insulin/IGF and TOR signalling network. J. Exp. Gerontol., 46(5): 376-381.

17. Kim, J.W. (2014) Modulation of the somatotropic axis in periparturient dairy cows. Asian Australas. J. Anim. Sci., 27(1): 147-154.

18. Thornton, K.J., Kamange-Sollo, E., White, M.E. and Dayton, W.R. (2016) Active G protein-coupled receptors (GPCR), matrix metalloproteinases 2/9 (MMP2/9), heparin-binding epidermal growth factor (hbEGF), epidermal growth factor receptor (EGFR), erbB2, and insulin-like growth factor 1 receptor (IGF-1R) are necessary for trenbolone acetate-induced alterations in protein turnover rate of fused bovine satellite cell cultures. J Anim. Sci., 94(6): 2332-2343.

19. Ventura, E.R., Konigorski, S., Rohrmann, S., Schneider, H., Stalla, G.K., Pischon, T., Linseisen, J. and Nimptsch, K. (2019) Association of dietary intake of milk and dairy products with blood concentrations of insulin-like growth factor 1 (IGF-1) in Bavarian adults. Eur. J. Nutr., 59(4): 1413-1420.

20. Rose, T.E.C. and Weekes, P.R. (2005) Correlation of blood and milk components with the milk yield response to bovine somatotropin in dairy cows. Domest. Anim. Endocrinol., 28(3): 296-307.

21. Simonov, M.R., Vlizlo, V.V. and Petruh, I.M. (2016) Plasma concentrations of insulin-like growth factor, triiodothyronine, thyroxine and insulin in cows during different physiological states. Agric. Sci. Pract., 3(3): 17-21.

22. Xu, C., Xu, Q., Chen, Y., Yang, W., Xia, C., Yu, H., Zhu, K., Shen, T. and Zhang, Z. (2015) The relationship between fibroblast growth factor-21 and characteristic parameters related to energy balance in dairy cows. BMC Vet. Res., $11: 271$.

23. Simonov, M. and Vlizlo, V. (2015) Some blood markers of the functional state of liver in dairy cows with clinical ketosis. Bulg. J. Vet. Med., 18(1): 74-82.

24. Meyer, Z., Höflich, C., Wirthgen, E., Olm Harald, S. and Hoeflich, A.H. (2017) Analysis of the IGF-system in milk from farm animals occurrence, regulation, and biomarker potential. Growth Horm. IGF Res., 35: 1-7.

25. Sutariya, S., Sunkesula, V., Kumar, R. and Shah, K. (2018) Review: Milk and milk products, insulin-like growth factor-1 and cancer. EC Nutr., 13(11): 696-705.

26. Kok, A., Chen, J., Kemp, B. and van Knegsel, A.T.M. (2019) Review: Dry period length in dairy cows and consequences for metabolism and welfare and customised management strategies. Animal, 13(1): 42-51.

27. Malekinejad, H. and Rezabakhsh, A. (2015) Hormones in dairy foods and their impact on public health a narrative review article. Iran. J. Public Health, 44(6): 742-758.

28. The Free Encyclopedia Wikipedia; 2020. Available from: https://en.wikipedia.org/wiki/Bovine_somatotropin. Retrieved on 16-11-2021. 